\title{
Coal industry of East Siberia - prospects for development
}

Liudmila Takaishvili ${ }^{*}$, and Aleksander Sokolov, Melentiev Energy Systems Institute of Siberian Branch of the Russian Academy of Sciences, Irkutsk, Russia

\begin{abstract}
The paper presents the analysis of the current state of coal industry in East Siberia: coal production, processing and delivery. The coal reserves are characterized. The deposits promising for coal production development are presented. The possibilities of increasing coal production and export are studied. The projects on the development of deposits are evaluated. The promising areas for using East Siberian coals, which determine the prospects for coal production development, are described.
\end{abstract}

\section{Introduction}

The coal industry occupies an important place in the resource provision of East Siberia and has a high social significance as a mainstay industry of coal production entities of the federation. Coal plays a leading role in the energy balance of East Siberia. In the European regions of the Russian Federation (RF) the main type of fuel for thermal power plants is gas, in Siberia and the Far East - coal. In the structure of fuel consumption by the federation entities of East Siberia its share amounts to more than $70 \%$, whereas in the country as a whole the coal share is $16 \%$. In addition, coal consumption decreases both in the country and East Siberia. East Siberian coals are consumed in the regions of coal production, supplied to other regions of Russia and for export. An export component in coal supplies increases. By virtue of the high social and economic significance of coal industry of East Siberia it seems challenging to study the prospects for coal industry development in East Siberia.

\section{Current state}

About a quarter of coal production in the whole country is mined in East Siberia, mainly by surface mining [1]. In supplies for export from Russia, the share of East Siberian coals is more than $10 \%$ [2]. Until 2014, only energy coal was mined. The coals of East Siberia are consumed in the production regions and are supplied in small quantities to the regions of Russia and for export $[1,2]$.

East Siberia plays a leading role in the use of coal at thermal power plants. Electric power in East Siberia is also generated by hydro power plants. The largest hydro power plants in the country operate in East Siberia (in the Irkutsk Region and the Krasnoyarsk

* Corresponding author: lusi@isem.irk.ru 
Territory). This fact explains essential fluctuations in the levels of production, supply and consumption of East Siberian coals as a result of fluctuations in coal demand due to climatic factors: water content of the rivers; warm or cold winter (Table 1). Coal production in East Siberia tends to increase. The main increase in production was observed in the Republics of Khakassia and Buryatia, the Trans-Baikal Territory. Relatively stable production volumes were in the Krasnoyarsk Territory and the Tyva Republic and a decrease was in the Irkutsk Region.

Table 1 Characteristic of coal industry in East Siberia

\begin{tabular}{|l|c|c|c|c|c|c|c|}
\hline \multirow{2}{*}{ Indicator } & \multicolumn{7}{|c|}{ Year } \\
\cline { 2 - 9 } & $\mathbf{2 0 0 0}$ & $\mathbf{2 0 0 5}$ & $\mathbf{2 0 1 2}$ & $\mathbf{2 0 1 3}$ & $\mathbf{2 0 1 4}$ & $\mathbf{2 0 1 5}$ & $\mathbf{2 0 1 6}$ \\
\hline Production & 78 & 73.2 & 92.4 & 89.9 & 87.1 & 91 & 94 \\
\hline Processing & 3.8 & 5.9 & 17.3 & 19.5 & 23.2 & 24.2 & 25.2 \\
\hline Supplies, including: & 78.8 & 72.4 & 81.6 & 78.4 & 76 & 78.6 & 76.8 \\
\hline - export & 1.7 & 6.3 & 15.1 & 15.4 & 17.7 & 18.4 & 19.0 \\
\hline - regions of Russia & 78.8 & 66.1 & 66.5 & 63.0 & 58.3 & 60.2 & 57.8 \\
\hline East Siberia & 63.5 & 56.6 & 56.0 & 52.1 & 47.3 & 48.4 & 46.0 \\
\hline West Siberia & 3.5 & 3.3 & 5.3 & 5.8 & 5.5 & 6.7 & 6.9 \\
\hline Far East & 7.5 & 3.9 & 2.3 & 2.0 & 1.4 & 1.5 & 1.4 \\
\hline Other regions & 4.3 & 2.3 & 3.0 & 3.2 & 4.0 & 3.6 & 3.5 \\
\hline \multicolumn{1}{|c|}{ Source: $[2-3]$} & & & & & &
\end{tabular}

Supplies of East Siberian coals to the regions of Russia tend to decrease in parallel with an increase of export supplies. Mostly the Chita and Kansk-Achinsk coals are supplied to the Far East, the Khakass and Kansk-Achinsk coals - to the European regions and Ural.

Principally, coal consumption in the country decreased. Consumption of East Siberian coals in particular, decreased from 80.4 million tons in 2000 to 58.7 million tons in 2016. The share of East Siberian coals in total consumption fell from $38.7 \%$ to $32.7 \%$. Supplies of the coals from East Siberia for export increased almost threefold as compared with 2005 and totaled 31.2 million tons in 2016: $20 \%$ of the supplies from Russia and $48 \%$ of the supplies for export in the eastern direction.

In the structure of internal coal consumption in East Siberia, the share of power and boiler plants is $97 \%$, the share of industry is $2.5 \%$, and the share of population is $0.5 \%$. The decrease in coal consumption is due to gas and electricity supplies to consumers instead of coal.

The increase in coal production and processing in East Siberia is explained by the increase in coal export from the Republic of Khakassia and the Trans-Baikal Territory.

\section{Coal reserves}

As of January 1, 2016, the coal reserves forming the mineral resource base of East Siberia are very heterogeneous in their composition and industrial significance (Table 2) [4]. Brown coals predominate in the balance reserves $-71.7 \%$ of reserves. About $84.6 \%$ of balance reserves, mainly of brown coals, are suitable for surface mining.

The explored reserves are distributed in the region, basins and deposits unevenly. The balance reserves of brown coals of categories $\mathrm{A}+\mathrm{B}+\mathrm{C}_{1}$ are located in the Krasnoyarsk Territory ( $87 \%$ of the brown coal reserves in East Siberia) and the Trans-Baikal Territory (5\%). in the Irkutsk Region (4\%) and the Republic of Buryatia (3\%). Hard coals are explored in the Irkutsk Region (35\% of the hard coal reserves of East Siberia), the Republic of Khakassia (31\%) and the Krasnoyarsk Territory (19\%). 
Table 2 Structure of coal reserves of East Siberia. billion tons

\begin{tabular}{|l|c|c|c|c|}
\hline \multirow{2}{*}{ Region / Type of coal } & \multicolumn{4}{c|}{ Balance reserves by category } \\
\cline { 2 - 5 } & $\mathbf{A}+\mathbf{B}+\mathbf{C} \mathbf{1}$ & $\mathbf{C}_{\mathbf{2}}$ & $\begin{array}{c}\text { Total } \\
\mathbf{A}+\mathbf{B}+\mathbf{C}_{\mathbf{1}}+\mathbf{C}_{\mathbf{2}}\end{array}$ & Off-balance \\
\hline Total, including: & 68.2 & 29.7 & 97.9 & 25.2 \\
\hline Brown & 49.0 & 21.2 & 70.2 & 9.6 \\
\hline Hard & 18.8 & 8.4 & 27.3 & 15.6 \\
\hline - coking & 4.8 & 1.9 & 6.7 & 1.2 \\
\hline - particularly valuable ranks & 2.8 & 1.0 & 3.8 & 0.3 \\
\hline For surface mining, including: & 58.7 & 24.1 & 82.8 & 13.3 \\
\hline Brown & 47.5 & 19.6 & 67.1 & 8.5 \\
\hline Hard & 11.1 & 4.5 & 15.6 & 4.8 \\
\hline - coking & 0.8 & 0.0 & 0.8 & 0.1 \\
\hline \multicolumn{2}{|c|}{ Sourd }
\end{tabular}

Source: [4]

Most of the deposits in East Siberia are characterized by favourable conditions for coal occurrence: a greater number of coal seams, presence of powerful flat seams with shallow occurrence, which allows developing the deposits by the most effective surface mining. Coal reserves for surface mining are distributed as follows: in the Krasnoyarsk Territory $80 \%$, the Irkutsk Region $-13 \%$, the Trans-Baikal Territory $-5 \%$ and other regions $-2 \%$. At the 2016 production levels, the availability of coal reserves is more than 800 years.

\section{Capabilities of production and new projects}

The Program of the coal industry development in Russia until 2030, which was adopted in June 2014, provides for the main development of coal production in the eastern regions of Russia [5]. The projects deal with new construction, full use and expansion of existing capacities. The goal of the large-scale development of coal production is the increase of coal export to the East, the construction of coal-fired power plants for local needs and electricity export, and the development of coal chemical industry. The development of coal production in the eastern regions is also provided for by the regional programs: The State Program "Socioeconomic development of the Far East and Baikal region" and the strategies for the socioeconomic development of the regions of East Siberia and the Far East.

The policy documents contain the projects on coal production development, the implementation of which is planned for 2025-2030 in the deposits of East Siberia. The submitted projects are in varying degrees of implementation. According to the projects, the total production can amount to 300 million tons, 230 million tons of which are due to new construction (Table 3 and Table 4).

In the Tyva Republic, the following deposits are promising for development: Mezhegeiskoye. Elegest, the western part of the Ulughem basin and Kaa-Khem (Table 3). Coal is planned to be processed at the dressing works and supplied for export. 
Table 3 Promising coal deposits in East Siberia, new construction

\begin{tabular}{|c|c|c|c|c|c|c|}
\hline \multirow{2}{*}{ Deposit } & \multirow{2}{*}{$\begin{array}{l}\text { Reserves. } \\
\text { million } \mathrm{t}\end{array}$} & \multirow{2}{*}{$\begin{array}{c}\text { Potential } \\
\text { production. } \\
\text { million t }\end{array}$} & \multicolumn{4}{|c|}{ Qualitative characteristics } \\
\hline & & & $Q^{r}, \mathbf{M J} / \mathbf{k g}$ & $A^{d}, \%$ & $S^{d}, \%$ & $\mathbf{W}^{\mathrm{r}}, \%$ \\
\hline \multicolumn{7}{|c|}{ Tyva Republic } \\
\hline Mezhegeyskoye & 213.2 & 10 & 31 & 8.2 & 0.47 & $0.8-1.5$ \\
\hline Elegestoye & 775.4 & 15 & 31 & $3.1-21$ & $0.3-0.9$ & $0.5-1$ \\
\hline Western part of Ulughem basin & 415.4 & 9 & 31 & 7 & 0.45 & $0.6-2$ \\
\hline Kaa-Khem & 286.8 & 10 & 31 & $3.1-21$ & 0.3 & $0.7-1$ \\
\hline \multicolumn{7}{|c|}{ Republic of Khakassia } \\
\hline Beiskoye & 2923.8 & $8-30$ & $22-27$ & $7.5-22$ & $0.2-1.0$ & $2.3-5.2$ \\
\hline \multicolumn{7}{|c|}{ Krasnoyarsk Territory } \\
\hline Berezovskoye & & & 16 & $5.8-12$ & $0.2-0.5$ & $30-34$ \\
\hline Abanskoye & 16766.8 & 35 & $14-16$ & $8-15$ & $0.3-0.8$ & $31-38$ \\
\hline \multicolumn{7}{|c|}{ Irkutsk Region } \\
\hline Ishideyskoye & 831.7 & 12 & $21-31$ & $17-20$ & $0.5-1.8$ & $14-15$ \\
\hline Voznesenskoye & 518.6 & 8 & $23-33$ & $15-29$ & $0.9-1.5$ & $7.8-16$ \\
\hline Kharantsaiskoye & 3080.5 & 4 & 22 & 15 & 3.4 & $8.8-11.8$ \\
\hline \multicolumn{7}{|c|}{ Republic of Buryatia } \\
\hline Nikolskoye & 173.5 & 14.5 & 24 & 18 & $0.4-0.9$ & 6 \\
\hline Zagustaiskoye & 123.0 & 4.5 & 19 & 22 & 0.7 & 24 \\
\hline \multicolumn{7}{|c|}{ Trans-Baikal Territory } \\
\hline $\begin{array}{l}\text { Zashulanskoye, } \\
\text { Krasnochikoyskoye }\end{array}$ & 837.5 & $15-20$ & $18-23$ & $10-19$ & $0.5-0.7$ & $6-25$ \\
\hline Apsatskoye & 87.7 & 9 & 27 & 17 & 0.4 & $2-5$ \\
\hline Deposits of Priargun group & 360 & 4.5 & $14.9-16.6$ & $23-32$ & $0.3-0.8$ & $15-22$ \\
\hline Chikandinskoye & 12.5 & 1.2 & 22 & $17-23$ & $0.1-0.4$ & $1.5-7$ \\
\hline
\end{tabular}

Table 4 Projects on coal production development at the existing enterprises of East Siberia

\begin{tabular}{|l|c|}
\hline \multicolumn{1}{|c|}{$\begin{array}{c}\text { Federation entity of East Siberia, } \\
\text { deposit }\end{array}$} & $\begin{array}{c}\text { Existing/new capacity, } \\
\text { million t/ year }\end{array}$ \\
\hline \multicolumn{2}{|c|}{ Republic of Khakassia } \\
\hline Izykhskoye & $1.2 / 4.6$ \\
\hline \multicolumn{2}{|c|}{ Krasnoyarsk Territory } \\
\hline Borodinskoye & $21 / 1^{*}$ \\
\hline Berezovskoye & $13.5 / 13.5^{*}$ \\
\hline Abanskoye & $0.8 / 35$ \\
\hline \multicolumn{2}{|c|}{ Irkutsk Region } \\
\hline Mugunskoye & 1.13 \\
\hline Golovinskoye & $5 / 15$ \\
\hline \multicolumn{2}{|c|}{ Trans-Baikal Territory } \\
\hline Kharanorskoye & \\
\hline Note: * incomplete use of production capacity (50-90\%)
\end{tabular}

A draft program was elaborated for the creation and development of the Beisky coal cluster until 2030 in the Republic of Khakassia [9]. Extracted coal will be washed and processed. In addition, it is planned to introduce an installation for coal processing into semi-coke and gas and an installation for production of liquid fuel and chemical products.

The promising brown coal deposits of the Kansk-Achinsk basin in the Krasnoyarsk Territory are: Borodinskoye. Berezovskoye and Abanskoye. Energy coal production in the Krasnoyarsk Territory can be increased owing to: the use of production capacity of the 
existing Berezovsky and Borodinsky brown coal surface mines and the construction of two new surface mines.

At the Mugunskoye brown coal deposit in the Irkutsk Region, it is possible to expand the capacity of the surface mine and build a coal-fired power plant. The total production at new enterprises of the hard coal deposits in the Irkutsk basin: Voznesenskoye. Karantsaiskoye and Ishideiskoye, can reach up to 24 million tons. The development of the Karantsaiskoye deposit can be restrained by difficult hydrological conditions and high sulfur content in coal.

In the Republic of Buryatia, up to 19 million tons can be mined owing to new construction at the Nikolskoye and Zagustaiskoye deposits.

In the Trans-Baikal Territory, it is possible to expand the capacity of the existing surface mine at the Kharanorskoye deposit. The projects on development of the Priargun group (Kutimskoye. Pogranichnoye. Priozernoye) and the Chikoy depression (Zashulanskoye, Krasnochikoiskoye) provide for the construction of surface mines. It is planned that the extracted coal will be used for energy needs (construction of three thermal power plants), by other consumers and for export to China.

\section{Prospects for development of coal production and consumption}

According to the scenarios of the economy and energy development that were elaborated at Melentiev Energy Systems Institute of SB RAS [10,11] and the authors' estimates based on the established trends in coal consumption and the analysis of policy documents, the internal demand for East Siberian coals by 2020 can range from 29 to 47 million tce, of which from 24 to 41 million tce at thermal power plants, and by 2030 it can range from 30 to 61 million tce, of which from 26 to 54 million tce at thermal power plants. The maximum coal demand corresponds to the scenario, which envisages the growth in export supplies (Table 5), the construction of export coal-fired power plants [11] and the development of coal chemistry. The export supplies (Table 5) can be increased by the growth in coal processing up to 27-33 million t/year by 2020 and up to $30-40$ million t/year by 2030 . The greatest increase in coal washing is possible in the Trans-Baikal Territory and the Tyva Republic. Resources (lowgrade products of washing) to the energy sector after the coal washing from the Tuva coking coal deposits can reach up to 8 million $\mathrm{t} /$ year. The lack of demand for these products can hold back the development of washing and export supplies.

Table 5 Coal export, million $\mathrm{t} /$ year

\begin{tabular}{|l|c|c|c|}
\hline \multirow{2}{*}{ Federation entities of East Siberia } & \multicolumn{3}{|c|}{ Year } \\
\cline { 2 - 4 } & $\mathbf{2 0 1 6}$ & $\mathbf{2 0 2 0}$ & $\mathbf{2 0 3 0}$ \\
\hline & actual & forecast & \\
\hline Total & 18.78 & $20-30$ & $23-39$ \\
\hline Trans-Baikal Territory & 9.97 & $10-13$ & $12-15$ \\
\hline Republic of Khakassia & 5.86 & $6-7$ & $6-9$ \\
\hline Krasnoyarsk Territory & 2.06 & $2-3$ & $2-3$ \\
\hline Irkutsk Region & 0.89 & 1 & 1 \\
\hline Republic of Tyva & - & $1-6$ & $2-11$ \\
\hline
\end{tabular}

In the future the most probable increase in coal demand is possible in the following areas: power plants (including electricity export), export, deep processing and coal chemistry, integrated use of coal deposits (creation of coal clusters).

Coal consumption by boiler plants and other consumers will decrease with a rather high probability. 
The coal production can increase (Table 6) owing to:

- the increase in export supplies from the Republics of Tyva, Khakassia, Buryatia and the Trans-Baikal Territory;

- the construction of coal-fired power plants in the Trans-Baikal Territory and the Irkutsk Region for electricity export;

- the development of coal chemistry in the Krasnoyarsk and Trans-Baikal Territories, the Republic of Khakassia.

The considerable growth of coal production is possible practically in all federation entities of East Siberia.

Table 6 Forecast of coal production development, million t/year

\begin{tabular}{|l|c|c|c|}
\hline \multirow{2}{*}{ Federation entity of East Siberia } & \multicolumn{3}{|c|}{ Year } \\
\cline { 2 - 4 } & 2016 & $\mathbf{2 0 2 0}$ & $\mathbf{2 0 3 0}$ \\
\cline { 2 - 4 } & actual & forecast & \\
\hline Total & 94.03 & $99-136$ & $109-170$ \\
\hline Republic of Tyva & 0.76 & $2-10$ & $6-20$ \\
\hline Republic of Khakassia & 20.04 & $22-0$ & $25-35$ \\
\hline Krasnoyarsk Territory & 38.53 & $39-50$ & $39-60$ \\
\hline Irkutsk Region & 10.85 & $11-2$ & $12-20$ \\
\hline Republic of Khakassia & 2.38 & $3-4$ & $3-5$ \\
\hline Trans-Baikal Territory & 21.48 & $22-30$ & $24-30$ \\
\hline
\end{tabular}

\section{Conclusions}

The key problems of coal industry development in East Siberia in the previous years were and remain in the future:

- the socioeconomic problems caused by the decrease in coal demand both in the country and beyond its borders;

- the instability of coal prices in the world market and the environmental policy of the coal importing countries;

- the difficult conditions for development of some deposits;

- the incomplete use of production capacities of coal mines and surface mines;

- the insufficiently developed transport infrastructure primarily in the areas of promising deposits;

- the environmental constraints on development of individual deposits and coal-based generation;

- the shortage of investment and other resources;

- the high internal tariffs of coal transportation;

- the non-obvious competitiveness of coal chemistry products in terms of low prices of hydrocarbon fuels.

In the considered future the strategic priorities in coal industry development of East Siberia remain the following:

- the reliable provision of the regional economy and population and export needs with high-grade solid fuel and products of its processing;

- the promotion of competitiveness of the coal products in context of the market saturation with alternative energy resources;

- the sustainable and safe development of coal industry on the basis of the advanced scientific-technological potential and the environmentally compatible standards. 
Analysis of the retrospectives of coal industry development in East Siberia shows instability in the dynamics of coal production with an increase in exports and a decrease in supplies to the internal market.

East Siberia has sufficient coal resources and reserves to meet its own demand for coal, export deliveries and development of coal production for output of high value-added products.

Due to the sluggishness of coal industry development, the inconsistency of projects with the real demand for coal and other reasons, the deadlines of the projects are usually shifted or postponed to an uncertain period.

In order to improve the competitiveness of coal products, it is necessary to create modern enterprises oriented to the output of highly profitable, competitive, innovative products on the basis of efficient and cost-effective technologies satisfying the environmental standards.

From the standpoint of the ecology and economy the most promising area of coal use is the creation of coal clusters. Coal clusters may include both coal production and coal processing enterprises, and cogeneration plants on coal or low-grade products of coal washing, cogeneration plants on gas from coal seams, enterprises for processing of coal production waste, slag and gases from cogeneration plants. enterprises for deep processing of coal and others. Each coal deposit is unique in its geological and hydrological conditions, coal quality and chemical composition. availability of transport and social infrastructures. For these reasons, the projects on creation of coal clusters are individual for each deposit.

As a result of the implementation of measures to improve the competitiveness of coal products, it is possible to increase the export supplies and diversify the coal products [12], namely:

- different types of refined solid fuel;

- synthetic gaseous and liquid fuel;

- rare and rare-earth elements;

- construction materials;

- fertilizers, sorbents and other chemical products and raw material.

At the same time, the improvement of the environmental situation and social stability in the regions of coal production and coal fuel consumption should be a socially significant result.

\section{Acknowledgements}

The study was carried out within the framework of the scientific project XI.174.2 of the fundamental research program of SB RAS, reg. No. AAAA-A17-117030310435-0.

\section{References}

1. I.G. Tarzanov. Results of the coal industry operation in Russia for 2016. Coal, No. 3, pp. 36-51 (2017). DOI: http://dx.doi.org/10.18796/0041-5790-2017-3-36-50

2. Statistical and analytical information materials on the main indicators of production activity of coal industry enterprises in Russia. CDD FEC (Central Dispatching Department of Fuel and Energy Complex), (from 2000 to 2017)

3. Report on electric power industry operation for 2016 (tentative) / Moscow, March 2017, Russian Energy Agency of the Ministry of Energy of Russia. Retrieved from: http://www.bigpowernews.ru/photos/0/0_CXq7NsBUWeunnVlogf7uolVy4SB2XcBA. pdf (2018) (in Russian) 
4. State balance sheet of mineral reserves of the Russian Federation as of January 1. 2016. Issue 91. Coal. I. Summary data., M.: Ministry of Natural Resources and Environment of the Russian Federation. Federal Agency for Subsoil Management. Russian Federal Geological Foundation, 382 p. (2016) (in Russian)

5. Program of coal industry development in Russia for the period until 2030. Ministry of Energy of the Russian Federation. Moscow, 178 p. (2014) (in Russian)

6. State balance sheet of mineral reserves of the Russian Federation as of January 1. 2016. Issue 91. Coal. Volume VII. Siberian Federal District, part 2. M.: Ministry of Natural Resources and Environment of the Russian Federation. Federal Agency for Subsoil Management. Russian Federal Geological Foundation, 314 p. (2016) (in Russian)

7. Coal base of Russia. Volume III. Coal basins and deposits of East Siberia. Southern part (Kansk-Achinsk coal basin in the Krasnoyarsk Territory; Minusinsk basin in the Republic of Khakassia; Ulugkhem basin in the Republic of Tyva; Irkutsk basin and coal deposits of the Pre-Baikal area of the Irkutsk Region.). M.: CJSC "Geoinformmark", 488 p. (2002) (in Russian)

8. Coal base of Russia. Volume IV. Coal basins and deposits of East Siberia (Tunguska and Taimyr basins; deposits of the Trans-Baikal area). M.: CJSC "Geoinformmark", 493 p. (2001) (in Russian)

9. KEF. Construct clean - Khakassia offered the challenge: be the second in the country on coal production. Coal of Kuzbass, No. 2 (049), pp. 14-15 (2016) (in Russian)

10. A.V. Lagerev, V.N. Khanaeva. Priorities in energy sector development in the Asian regions of Russia on a long-term horizon. Spatial economics, No. 3, pp. 154-166 (2017) (in Russian). DOI: 10.14530/se.2017.3.154-166

11. K.S. Smirnov An integrated assessment of implementation of the projects on Russian electric power export from East Siberia to China. Bulletin of Irkutsk State Technical University, V. 21, No. 10, pp. 131-137 (2017) (in Russian). DOI: 10.21285/18143520-2017-10-131-137

12. V.V. Kuleshov Strategic projects on development of the most important economic complexes in Siberia. Region, No.1, pp. 94-112 (2006) (in Russian) 